\title{
Perbandingan Pengetahuan, Sikap, dan Keikutsertaan Vasektomi Antara Konseling dengan Pendekatan Health Belief Model dan Standar pada Pasangan Usia Subur (PUS) Di Kota Banjar
}

Heni Masri, ${ }^{1}$ Dwi Prasetyo, ${ }^{2}$ Yoni F. Syukriani, ${ }^{3}$ Farid Husin, ${ }^{4}$ Bambang S. Noegroho, ${ }^{5}$ Henni Djuhaeni. ${ }^{6}$

${ }^{1}$ Program Studi Magister Kebidanan, Fakultas Kedokteran, Universitas Padjadjaran

${ }^{2}$ Departemen Ilmu Kesehatan Anak Fakultas Kedokteran Universitas Padjadjaran

${ }^{3}$ Departemen Ilmu Kedokteran Forensik dan Medikolegal Fakultas Kedokteran Universitas Padjadjaran

${ }^{4}$ Departemen Epidemiologi dan Biostatistika Fakultas Kedokteran Universitas Padjadjaran

${ }^{5}$ Departemen Urologi Fakultas Kedokteran Universitas Padjadjaran

${ }^{6}$ Departemen Ilmu Kesehatan Masyarakat Fakultas Kedokteran Universitas Padjadjaran

\begin{abstract}
Abstrak
Program KB di Indonesia tidak hanya diperuntukkan bagi wanita melainkan juga bagi pria. Partisipasi pria menjadi salah satu indikator keberhasilan program KB. Namun partisipasi pria dalam vasektomi masih rendah. Selama ini konseling yang dilakukan belum optimal. Konseling yang dilakukan dengan pendekatan Health Belief Model (HBM) berpotensi meningkatkan pengetahuan, sikap dan keikutsertaan vasektomi. Tujuan penelitian ini untuk menganalisis perbandingan konseling berdasarkan teori HBM dengan konseling standar dalam meningkatkan pengetahuan, sikap dan keikutsertaan pria PUS dalam vasektomi.Penelitian ini menggunakan rancangan eksperimen semu dengan model pre test-post test with control group designyang dilakukan pada setiap kelompok 25orang pria pasangan usia subur dan pengambilan sampel dilakukan teknik random berstrata (stratified random sampling) dari setiap kecamatan di wilayah Kota Banjar. Pengetahuan dan sikap diukur dengan kuesioner. Analisis data menggunakan uji Chi-Kuadrat dan uji Mann-Whitney. Hasil penelitian menunjukkan perbedaan yang bermakna pada skor pengetahuan, sikap dan keikutsertaan setelah dilakukan konseling dengan pendekatan HBM dengan nilai $\mathrm{p}<0,05$. Konseling dengan pendekatan Health Belief Model tentang vasektomi mampu meningkatkan pengetahuan, sikap dan keikutsertaan vasektomi pria usia subur (PUS).
\end{abstract}

Kata kunci: Health Belief Model, konseling, keikutsertaan, pengetahuan, sikap, vasektomi. 


\title{
Comparative Study of Knowledge, Attitude, and Participation Vasectomy Based on Health Belief Model Theory andStandard Counseling of Men from Fertile-Age-Couples in Banjar Municipality
}

\begin{abstract}
In Indonesia, family planning program is not only implemented for women but also for men. Participation of men in family planing program is one ofthe indicators of successful family planning program to contribute in creating good quality of family. However, vasectomy as a participation of men in family planing program is still low. One of the factors which influnced the low participation was caused by the lack of knowledge and attitude towards vasectomy. In order to improve men's knowledge and attitude towards vasectomy there is standard counseling method. We considered that counseling program based on Health Belief Models (HBM) couldbe an alternative to change clients' perception and believe that vasectomy is important for their health. This study was aimed to compare the difference between Health Believe Model based counseling with standard counseling in increasing knowledge, attitude, and participation of men from fertile age couples in vasectomy.This study used quasy experimental approach using pre test and post test with control group design. Samples were determined by using stratified simple random tecnique. The participants were involved were 25 men fertile-agecouples in each group, taken from all sub-districts in Banjar municipality. Data were analysed using Chi-Square and Mann-Whitney test.Results indicate that there is significant difference in knowledge improvement, attitude and participationbetween control and experimental group, with $\mathrm{p}<0.05$. Based on these results it can be concluded that Health Believe Model based vasectomy counseling method is more effective than standard counselingmethod in improving knowledge and participation towards vasectomy of men from fertile-age-couples.
\end{abstract}

Keywords: Counseling, Health Belief Model, knowledge, participation, vasectomy.

\section{Pendahuluan}

Partisipasi pria menjadi salah satu indikator keberhasilan program KB (keluarga berencana) dalam memberikan kontribusi yang nyata untuk mewujudkan keluarga kecil berkualitas. Target peningkatan peserta $\mathrm{KB}$ aktif pria dari 3,6 persen menjadi sekitar 5 persen pada tahun 2014. Namun pencapaiannya masih rendah belum mencapai target yang ditentukan. ${ }^{1,2}$

Rendahnya keikutsertaaan suami dalam praktek penggunaan kontrasepsi pada dasarnya yaitu adanya anggapan atau persepsi yang masih cenderung menyerahkan tanggung jawab KB sepenuhnya kepada istri atau perempuan, karena wanita yang menjadi hamil, sehingga banyak metode kontrasepsi yang didesain untuk wanita, sedangkan metode kontrasepsi bagi pria sangat terbatas pengembangannya. ${ }^{2,3,7}$

Kurang berperannya suami dalam program KB disebabkan oleh pengetahuan suami mengenai KB secara umum relatif rendah, dan adanya rumor negatif mengenai vasektomi sebagaimana terungkap pada penelitian Suherni, dkk masih rendahnya partisipasi pria dalam pelaksanaan program KB baik dalam praktik $\mathrm{KB}$, mendukung istri dalam penggunaan alat kontrasepsi, sebagai motivator atau promotor dalam merencanakan jumlah anak, kejadian ini sejalan dengan belum meratanya pemberian informasi mengenai kontrasepsi $\mathrm{KB}$ pria dan masih adanya rumor negatif yang ada di masyarakat. ${ }^{3,7}$

Hasil penelitian yang dilakukan di Zambia menyatakan bahwa pria takut terjadi impotensi karena vasektomi, juga adanya salah persepsi dan pandangan yang negatif bahwa vasektomi itu sama dengan pengebirian, sehingga pria enggan untuk menjalani vasektomi. ${ }^{9}$

Hasil dari penelitian Kadir Tiya mengatakan bahwa sosialisasi dan konseling harus dilaksanakan sesering mungkin oleh tenaga kesehatan untuk menghilangkan stigma negatif dari masyarakat, karena pada kenyataannya petugas yang dominan memberikan konseling adalah PLKB. ${ }^{4}$

Upaya peningkatkan pengetahuan melalui promosi $\mathrm{KB}$ pria salah satunya menerapkan 
konseling HBM oleh tenaga kesehatan yang diharapkan akan menumbuhkan persepsi yang benar pada masyarakat terutama pria, sehingga mereka sadar dan dengan ikhlas ikut serta menjadi peserta KB Pria vasektomi. Konseling tentang vasektomi yang intensif memang harus dilakukan, mengingat banyaknya persepsi dan pemikiran yang salah tentang vasektomi. ${ }^{8,9}$

Kegiatan konseling standar tentang vasektomi sudah dilaksanakan oleh bidan kepada ibu dan suami calon akseptor vasektomi, yang memiliki istri dengan riwayat obstetri buruk, mempunyai anak lebih dari dua dan tidak menginginkan anak lagi. Hal ini disampaikan kepada petugas PLKB, motivator KB pria, dan kader agar dilakukan konseling lebih intensif ke rumah-rumah sasaran calon akseptor vasektomi. Apabila calon akseptor sudah mantap, diinformasikan untuk kembali ke tenaga medis. Namun angka keberhasilannya masih rendah, hal ini diduga karena konseling yang disampaikan belum dapat menggali/mengeksplorasi masalah klien, sehingga klien belum dapat merubah persepsi dan menyadari masalah juga kebutuhannya sendiri dalam mengambil keputusan ber-KB yang sesuai dengan kondisi kesehatannya. ${ }^{4,10}$

Konseling berdasarkan teori Health Belief Model (HBM) merupakan salah satu cara merubah persepsi dan keyakinan klien terhadap kesehatannya. Metode ini sudah banyak digunakan oleh para peneliti dalam penelitian perilaku kesehatan namun belum pernah diterapkan pada calon akseptor vasektomi. Konseling HBM terdiri dari: menyadari faktor risiko (perceived susceptibility), menyadari keparahan (perceived severity), menyadari manfaat (perceived benefits), menyadari hambatan (perceived barriers), isyarat untuk bertindak (cues to action), dan self eficacy. ${ }^{13}$

HBM merupakan kerangka kerja antara kognitif yang memandang bahwa manusia sebagai mahluk rasional yang menggunakan pendekatan multidimensi untuk pengambilan keputusan mengenai apakah akan melakukan perilaku kesehatan. Dimensinya berasal dari teori psikologi sosial yang sangat bergantung pada faktor-faktor kognitif berorientasi pada pencapaian tujuan (contohnya motivasi untuk mencegah kehamilan/ kehamilan yang tidak diinginkan dan resiko yang akan terjadi apabila hamil). ${ }^{17}$

Penelitian terkait dengan penerapan HBMtelah banyak dilakukan, diantaranya dilakukan oleh penelitian Kelli S.H (2013) tentang "The Health Belief Model Can Guide Modern Contraceptive Behavior Research And Practice" menunjukkan hasil penelitian bahwa HBM dalam program KB dapat meningkatkan pengetahuan dan perilaku ber$\mathrm{KB}$ yang sesuai dengan kebutuhan. HBM direkomendasikan untuk digunakan dalam memberikan intervensi konseling kontrasepsi modern untuk membantu klien dalam pengambilan keputusan dan mencegah kehamilan yang tidak diinginkan. ${ }^{17}$

Lebih lanjut penelitian Hasneli (2009) di Thailand menunjukkan hasil bahwa setelah mengikuti program pendidikan berbasis HBM, kelompok eksperimen memiliki skor perilaku diet lebih tinggi $(p<0,001)$ dari pada skor sebelum mengikuti program pendidikan berbasis HBM, dan skor perilaku diet kelompok eksperimen lebih tinggi dibandingkan kelompok kontrol $(p<0,001) .{ }^{16}$

Penelitian ini dilakukan konseling berdasarkan teori HBM tentang vasektomi untuk membuktikan hal tersebut diatas, dan dapat menggali/mengeksplorasi masalah klien, sehingga klien dapat merubah persepsi dan menyadari masalah juga kebutuhannya sendiri dalam mengambil keputusan ber-KB yang sesuai dengan kondisi kesehatannya.

\section{Metode}

Penelitian ini menggunakan eksperimen semu dengan model pre test - post test with control group design., yang dilakukan pada 50 responden yaitu pria pasangan usia subur di wilayah Kota Banjar, (Kelompok perlakuan 25 responden dan kelompok kontrol 25 responden).Pengambilan sampel pada penelitian ini dilakukan teknik stratified random samping.

Kriteria inklusisebagai berikut: a) Pria PUS mempunyai anak lebih dari dua,dan tidak ingin punya anak lagi. b) Umur istri $\leq 25$ tahun dan istrinya tidak ikut KB. c) Umur pria PUS $\leq 35$ tahun. d) Bersedia mengikuti penelitian dengan menandatangani lembar persetujuan. e) Bertempat tinggal tetap di Kota Banjar. 
Kriteria eksklusi penelitian ini adalah: Subjek penelitian yang tidak hadir saat diberi perlakuan dan subjek penelitian yang sedang sakit pada saat penelitian. Kriteria Drop Out penelitian ini adalah: Subjek penelitian yang tidak mengikuti seluruh kegiatan penelitian dan subjek penelitian yang tidak ingin melanjutkan keikutsertaannya pada saat penelitian berlangsung.

Kelompok perlakuan diberikan konseling Health Belief Model oleh Peneliti, Kelompok kontrol diberikan konseling standar oleh Bidan dan dimantapkan oleh PLKB. Pada kedua kelompok sebelumnya diberikan pretest dengan kuisioner pengetahuan, sikap yang diambil dari penelitian sebelumnya yaitu penelitian Budisantoso dan Ekarini. ${ }^{3,7}$ Dilakukan item analisis oleh pakar perilaku, kemudian diberikan konseling kepada masing masing kelompok sebanyak dua kali konseling, setelah konseling kedua dilakukan post test untuk melihat peningkatan pengetahuan, sikap, dukungan istri dan panutan/ keteladanan, kemudian setelah 1 bulan dilihat keikutsertaan vasektomi. Penelitian ini dilaksanakan pada bulan September s/d November 2015. Pengolahan dan analisis data menggunakan uji chi kuadrat dan uji mann withney. Kemaknaan hasil uji ditentukan berdasarkan nilai $\mathrm{p}>0,05$.

\section{Hasil}

Tabel 1. Karakteristik Subjek Penelitian

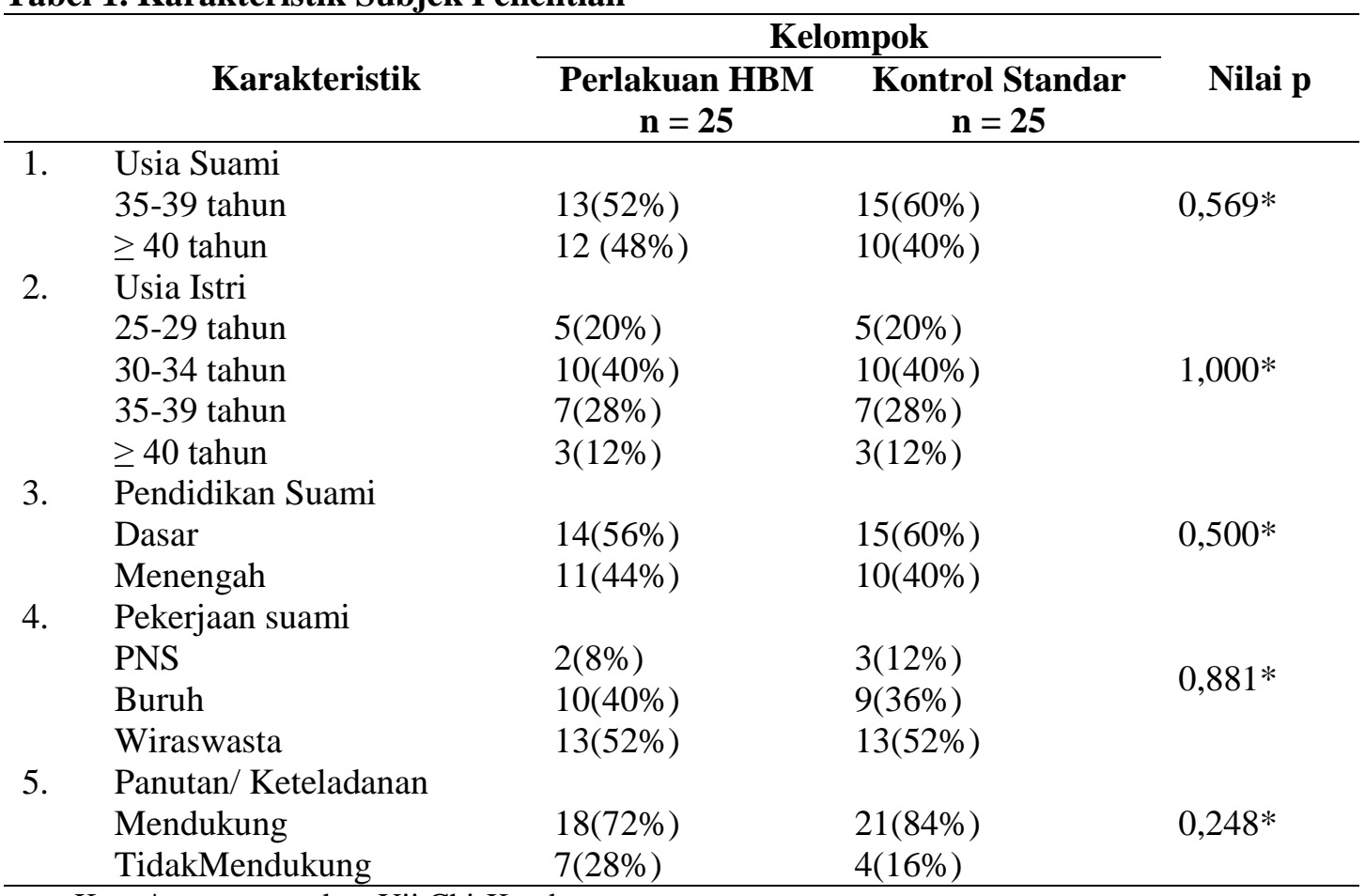

Ket : * menggunakan Uji Chi-Kuadrat

Berdasarkan tabel di atas karakteristik responden yang terdiri dari Usia suami, usia istri,pendidikan suami, pekerjaan suami, panutan/ keteladanan menunjukkan nilai p>0,05 antara kedua kelompok. Hal tersebut menggambarkan bahwa karakteristik antara kedua kelompok setara sehingga layak untuk diperbandingkan. 
Tabel 2. Perbandingan Persentase Kenaikan Skor Pengetahuan dan Sikap Pada Kelompok Perlakuan dan Kelompok Kontrol

\begin{tabular}{|c|c|c|c|}
\hline \multirow[b]{2}{*}{ Persentase Peningkatan } & \multicolumn{2}{|c|}{ Kelompok } & \multirow[b]{2}{*}{$\mathrm{p}^{*}$} \\
\hline & $\begin{array}{c}\text { Perlakuan HBM } \\
n=25\end{array}$ & $\begin{array}{c}\text { Kontrol Standar } \\
n=25\end{array}$ & \\
\hline Peningkatan Pengetahuan Suami & & & $<0,001$ \\
\hline Rata-rata & 86,08 & 69,88 & \\
\hline SD & 12,92 & 18,50 & \\
\hline Median & 88 & 80 & \\
\hline Rentang & $56-100$ & $24-88$ & \\
\hline Peningkatan Sikap & & & 0,018 \\
\hline Rata-rata & 86,37 & 58,88 & \\
\hline SD & 6,76 & 29,79 & \\
\hline Median & 81,60 & 82,40 & \\
\hline Rentang & $76,80-96,80$ & $22,40-93,60$ & \\
\hline
\end{tabular}

Ket : *menggunakan uji Mann Whitney

Tabel 2. menunjukkan perbandingan persentase kenaikan pengetahuan dan sikap antara kedua kelompok. Perbandingan persentase peningkatan pengetahuan dan sikap antara kedua kelompok naik secara bermakna dengan nilai $\mathrm{p}$ masing-masing <0,05. Namun peningkatan sikap yang lebih baik pada kelompok kontrol yaitu pada kelompok konseling standar.

Tabel 3. Keikutsertaan Vasektomi Pada Kelompok Perlakuan dan Kelompok Kontrol

\begin{tabular}{lll}
\hline \multirow{2}{*}{ Keikutsertaan Vasektomi } & \multicolumn{2}{c}{ Kelompok } \\
\cline { 2 - 3 } & $\begin{array}{c}\text { Perlakuan HBM } \\
\mathbf{n = 2 5}\end{array}$ & \multicolumn{1}{c}{$\begin{array}{c}\text { Kontrol Standar } \\
\mathbf{n = 2 5}\end{array}$} \\
\hline Ya & $14(73,7 \%)$ & $5(26,3 \%)$ \\
Tidak & $11(35,5 \%)$ & $20(64,5 \%)$ \\
\hline
\end{tabular}

Ket : $\mathrm{X}^{2}=6,876, p=0,009$

* menggunakan uji Chi-Kuadrat

Dari tabel tersebut, diketahui bahwa hasil pada kelompok perlakuan konseling HBM keikutsertaan menjadi akseptor vasektomi sebanyak $73,7 \%$. Konseling HBM yang terdiri dari: menyadari faktor risiko (perceived susceptibility) sebesar $68 \%$, menyadari keparahan (perceived severity) sebesar 76\%, menyadari manfaat (perceived benefits) sebesar $80 \%$, menyadari hambatan (perceived barriers) sebesar $68 \%$, isyarat untuk bertindak (cues to action) 68\%, dan self eficacy $56 \%$. Pada kelompok kontrol hanya $26,3 \%$ yang menjadi akseptor vasektomi. Perbandingan antara keikutsertaan vasektomi pada kelompok perlakuan dan kelompok kontrol dengan menggunakan analisis Chi Kuadrat dengan nilai $\mathrm{p}=0,009$.

\section{Pembahasan}

a. Karakteristik Subjek Penelitian

Berdasarkan hasil analisis karakteristik responden, baik pada umur responden, Pendidikan, pekerjaan, umur istri, dan panutan/keteladanan pada kedua kelompok homogen dan layak untuk dibandingkan. Tapi ada yang lebih tinggi yaitu dukungan dari panutan/ keteladanan dari tokoh masyarakat yang sudah menjadi akseptor vasektomi, terutama pada kelompok kontrol. 


\section{b. PerbandinganPeningkatan}

Pengetahuan, Sikap dan Keikutsertaan Pria antara Kelompok Perlakuan dan Kelompok Kontrol

Pengetahuan didapatkan salah satunya melalui pemberian informasi. Pemberian informasi menjadi salah satu hal yang harus diperhatikan. Pengetahuan yang benar tentang kontrasepsi pada pria merupakan prasyarat dasar untuk penggunaan kontrasepsi yang efektif. Penelitian Desmalia dan Budisantoso menunjukkan ada hubungan yang bermakna antara pengetahuan tentang KB dengan partisipasi pria dalam program $\mathrm{KB}^{31}$ Selain itu, perkembangan keikutsertaan KB pria stagnan berkaitan pula dengan dukungan istri, yang salah satunya dipengaruhi oleh kesulitan dan minimnya informasi kontrasepsi pada suami/ istri. ${ }^{7,21}$

Hasil penelitian Wahyuni, menyatakan bahwa pengetahuan dan sikap dalam penggunaan alat kontrasepsi setelah diberikan konseling KB lebih baik dari pada sebelum pemberian konseling. ${ }^{15}$

Pengetahuan yang baik tentang $\mathrm{KB}$ pria vasektomi akan membantu membentuk persepsi yang baik tentang program keluarga berencana dan kesehatan reproduksi. Persepsi ini selanjutnya akan membantu membentuk sikap individu terhadap objek yang diketahuinya. Objek yang telah diketahui dan disadari secara utuh akhirnya akan menimbulkan respons berupa tindakan, yaitu keikutsertaan menjadi akseptor vasektomi. ${ }^{7,15,22}$

Jika dikaitkan dengan tabel 2 dapat dilihat bahwa dengan pemberian konseling berdasarkan teori Health Belief Model mengenai vasektomi dapat meningkatkan pengetahuan suami sebelum perlakuan dibandingkan sesudah diberikan perlakuan dengan nilai $\mathrm{p}<0,001$. Pada kelompok kontrol juga didapatkan hasil yang sama yaitu terdapat peningkatan pengetahuan suami. Namun demikian, peningkatan pengetahuan pada suami ini lebih besar terjadi pada kelompok perlakuan dibandingkan pada kelompok kontrol.

Hasil penelitian ini diketahui bahwa konseling HBM dapat meningkatkan pengetahuan tentang vasektomi pada pria PUS. Hasil analisis yang telah dilakukan dengan menggunakan uji Mann-Whitney diketahui peningkatan nilai median pengetahuan kelompok perlakuan (88) lebih tinggi dibandingkan dengan kelompok kontrol (80) dan secara statistik peningkatan persen pengetahuan bermakna $(p<0,001)$.

Peningkatan pengetahuan ini dapat dijadikan salah satu modal dasar untuk pria pasangan usia subur dalam pengambilan keputusan menjadi akseptor Vasektomi. Hal ini sesuai dengan hasil penelitian Sariyono dkk yang mengungkapkan bahwa responden yang memiliki pengetahuan tinggi tentang KB cenderung lebih mungkin untuk memakai alat kontrasepsi dibandingkan dengan responden yang berpengetahuan rendah, serta ada hubungan yang signifikan antara tingkat pengetahuan dengan keikutsertaan kontrasepsi. ${ }^{61}$ Berdasarkan berbagai teori tersebut, dapat disimpulkan bahwa konseling berdasarkan teori Health Belief Model mengenai vasektomi merupakan salah satu cara untuk meningkatkan pengetahuan.

Tingginya tingkat pengetahuan ini ternyata tidak secara otomatis mendorong tingginya perubahan sikap dan keikutsertaan vasektomi pada pria PUS. Hal ini terlihat dari hasil analisis yang menunjukkan bahwa dari 25 responden, hanya 14 orang saja yang akhirnya menggunakan kontrasepsi dan 11 orang belum menggunakan kontrasepsi. Meski hasil analisis statistik menunjukkan peningkatan pengetahuan, namun pada kenyataannya peningkatan pengetahuan ini tidak selalu sejalan dengan keikutsertaan pria PUS dalam vasektomi. Hal ini terlihat dari beberapa alasan yang dikemukakan oleh responden yakni ketakutan karena efek samping dan sosial budaya yang masih menganggap bahwa anak adalah rezeki dari Tuhan. Selain itu, adanya pengaruh dari keluarga (orang tua atau mertua) terhadap pengambilan keputusan untuk menggunakan vasektomi. Jika dikaitkan dengan konseling berdasarkan health belief model yang digunakan dalam penelitian ini, pada konseling health belief model ini berisi tentang resiko yang sering terjadi pada pria PUS maupun istri yang tidak menggunakan $\mathrm{KB}$, tidak mencakup masalah mendalam tentang sosial budaya, yang dibahas secara khusus mengenai efek samping vasektomi 
berdasarkan asumsi masyarakat dan penjelasannya. Pria PUS masih sedikit yang menggunakan vasektomi, diduga masih kurangnya motivasi dan masih adanya pengaruh lingkungan sekitar yang mempengaruhi pandangan pria PUS tentang pentingnya penggunaan kontrasepsi. Namun, adanya peningkatan pengetahuan PUS tentang vasektomi ini memperlihatkan adanya peluang untuk pengembangan $\mathrm{KB}$ pria vasektomi di daerah penelitian.

Pengetahuan yang dimiliki oleh seorang calon akseptor akan memengaruhi keputusannya dan keberlangsungannya dalam ber-KB. Selain pengetahuan, sikap terhadap KB diperlukan dalam keikutsertaan vasektomi. Salah satu strategi perubahan perilaku adalah dengan pemberian informasi melalui konseling KB. Dengan memberikan informasi mengenai vasektomi maka didapatkan pengetahuan yang akan mempengaruhi sikap. Sikap yang positif menyebabkan pria berperilaku sesuai dengan pengetahuan yang dimilikinya dalam hal ini adalah partisipasi pria untuk ikut serta menjadi akseptor KB vasektomi.

Sikap merupakan kesiapan untuk bereaksi terhadap obyek dengan cara tertentu, bentuk dan reaksinya dapat positif atau negatif. Konseling promosi kesehatan merupakan semua sarana dan prasarana untuk menampilkan pesan atau informasi yang dapat meningkatkan pengetahuan yang akhirnya diharapkan dapat mengubah sikap dan perilakunya ke arah yang positif terhadap kesehatan. $^{21}$

Hal ini dapat dilihat pada tabel 2 yang menunjukkan adanya perbandingan peningkatan sikap pada kelompok perlakuan maupun pada kontrol dengan nilai $p<0,018$.

Hasil penelitian ini diketahui bahwa konseling HBM dapat meningkatkan sikap tentang vasektomi pada pria PUS. Hasil analisis yang telah dilakukan dengan menggunakan uji Mann-Whitney diketahui peningkatan nilai median sikap kelompok kontrol $(82,40)$ lebih tinggi dibandingkan dengan kelompok perlakuan $(81,60)$ dan secara statistik peningkatan persen pengetahuan bermakna ( $p<0,018)$. Disini peningkatan sikap pada kelompok kontrol lebih tinggi dibandingkan kelompok perlakuan, walaupun perbedaan peningkatannya sangat sedikit sekali $(0,8)$.
Ada beberapa hal diduga dapat menjelaskan fenomena tersebut yaitu 1. Panutan/ keteladanan dari tokoh masyarakat, karena pada hasil analisis karakteristik responden dukungan dari panutan/keteladanan tokoh masyarakat lebih tinggi pada kelompok kontrol. 2. Dukungan istri/keluarga, 3. Sosial budaya, 4. Agama, 5. Rumor yang beredar dimasyarakat.

Sikap seseorang untuk memilih menggunakan alat kontrasepsi dipengaruhi juga oleh faktor kekerabatan atau dukungan dari keluarga termasuk istri, panutan/ tokoh masyarakat yang lebih dipercaya, pengalaman yang tidak jelas dan informasi yang salah atau kurang tepat sehingga memengaruhi individu untuk menentukan sikap. ${ }^{23}$ Individu akan mempertimbangkan penggunaan metode kontrasepsi sangat dipengaruhi oleh pengetahuan mereka tentang kontrasepsi pada umumnya dengan penerimaan dari anggota keluarga dalam hal ini istri dan sosial budaya. Sikap seorang pria untuk menerima metode kontrasepsi dibentuk oleh pengetahuan mereka tentang metode yang akan digunakan.

Penelitian ini, peneliti mengelompokkan responden penelitian dalam 2 kelompok yaitu kelompok eksperimen dan kelompok kontrol. Pada kelompok eksperimen, responden diberikan konseling dengan pendekatan Health Belief Model. Hasil penelitian menunjukkan rata-rata pengetahuan responden (kelompok eksperimen) mengalami peningkatan sesudah mendapatkan konseling Health Belief Model.

Konseling dengan pendekatan Health Belief Model ini berfokus pada hubungan antara perilaku kesehatan, praktek dan pemanfaatan dengan tujuan membedakan masalah kesehatan dari perilaku kesehatan. ${ }^{14}$ Health belief model berkaitan dengan kepercayaan dalam kesehatan yang dirancang untuk membantu masyarakat dalam merubah sikap dan perilaku kesehatannya kearah yang positif. Metode ini menekankan peranan persepsi kerentanan, keparahan, manfaat dan hambatan terhadap suatu masalah yang dapat mengancam kesehatan mereka, sehingga masyarakat perlu diberikan pengetahuan mulai dari konsep masalah (pengertian, alasan, syarat, keuntungan, kerugian, rumor yang ada di masyarakat dan fatwa MUI) sampai dengan bagaimana pelaksanaan 
vasektomi dan perawatan pasca vasektomi. Konseling dengan pendekatan Health Belief Model diberikan agar pria PUS dapat merubah persepsi mereka tentang vasektomi, merubah perilaku positif mengenai vasektomi, dan melakukan vasektomi.

Responden pada kelompok kontrol tidak diberikan konseling dengan pendekatan Health Belief Model tetapi diberikan konseling standar. Hasil penelitian memperlihatkan terjadi sedikit peningkatan rata-rata pengetahuan pada kelompok kontrol yaitu sebelum dan sesudah konseling, terdapat perbedaan pengetahuan tentang vasektomi sebelum dan sesudah diberikan konseling dengan pendekatan Health Belief Model pada kelompok eksperimen.

PUS masih sedikit sekali yang menggunakan vasektomi, diduga masih kurangnya motivasi dan masih adanya pengaruh lingkungan sekitar yang mempengaruhi pandangan pria PUS tentang rumor penggunaan vasektomi.

Hal ini sejalan dengan penelitian yang dilakukan oleh Widodo dkk menyatakan bahwa sikap yang peduli terhadap masalah KB dan kesehatan reproduksi diyakini akan meningkatkan partisipasi dalam KB. Maka penting sekali meningkatkan pengetahuan dan mengubah sikap agar positif terhadap KB. ${ }^{22}$

Konseling merupakan suatu proses dimana seseorang membantu orang lain dalam membuat keputusan atau mencari jalan keluar untuk mengatasi masalah, melalui pemahaman tentang fakta-fakta dan perasaanperasaan yang terlibat didalamnya. Pengambilan keputusan bukan tugas seorang konselor KB. Fakta-fakta meliputi keterangan yang disampaikan klien seperti catatan kesehatan, latar belakang keluarga, harapanharapan dan rencana masa depan klien, atau harapan dan rencana masa depan istrinya. Perasaan klien seperti masalah yang sedang mereka alami, ketakutan-ketakutan dari rumor yang ada dimasyarakat, sikap dan nilai seksualitas, dan kesehatan anak merupakan tanggung jawab orang tua. ${ }^{20}$

Penelitian ini sesuai dengan hasil penelitian Fariba Mahamed yang menyimpulkan bahwa metode pendidikan kesehatan tentang keluarga berencana yang efektif dapat meningkatkan pengetahuan dan menimbulkan sikap yang baik terhadap program keluarga berencana. ${ }^{20}$

Gredler mengatakan bahwa proses perubahan sikap dan tingkah laku itu pada dasarnya berlangsung pada suatu lingkungan buatan dan sangat sedikit sekali yang berada pada situasi yang alami. Oleh karenanya konseling yang digunakan untuk menjembatani proses perubahan sikap tersebut harus dirancang menyerupai kondisi sasaran. Menurut Middlebrook yang dikutip Azwar mengemukakan bahwa tidak adanya pengalaman akan membentuk sikap negatif terhadap suatu objek. Pembentukan kesan ini merupakan proses kompleks dalam diri individu yang melibatkan individu tersebut, situasi dan ciri objektif yang dimiliki oleh stimulus. Untuk dapat membentuk sikap, harus ada pengalaman pribadi stimulus yang meninggalkan kesan yang kuat agar sikap lebih mudah terbentuk. ${ }^{5,15,22}$

Selain itu, aspek emosional dalam diri individu yang berakar paling dalam sebagai komponen sikap dan merupakan aspek yang paling berpengaruh yang akan mengubah sikap. Komponen perilaku berisi tendensi atau kecenderungan untuk bertindak atau bereaksi terhadap sesuatu dengan cara tertentu. Pembentukan sikap dipengaruhi oleh beberapa hal diantaranya, pengalaman pribadi, pengaruh orang lain yang dianggap penting, pengaruh kebudayaan, konseling massa, lembaga pendidikan dan lembaga agama serta pengaruh emosional. ${ }^{15,24}$

Dari penelitian ini dapat disimpulkan bahwa sikap terhadap penggunaan kontrasepsi adalah sejauh mana individu mempertimbangkan secara positif dan negatif sehingga menjadi yakin bahwa dengan menggunakan vasektomi kondisi kesehatan istri menjadi lebih baik, perkembangan dan pendidikan anak kelak terkontrol, jarak kelahiran antar anak yang diinginkan bisa tercapai sehingga terhindar dari kehamilan yang tidak diinginkan serta kematian ibu dan anak. ${ }^{17}$

Keikutsertaan Vasektomi antara kedua kelompok terdapat perbedaan yang signifikan. Hal ini dapat dilihat pada tabel 3 bahwa pada kelompok perlakuan yang mendapatkan konseling berdasarkan teori Health Belief Model yaitu 14 orang $(73,7 \%)$ dari 25 responden, sedangkan pada kelompok kontrol 
yang mendapatkan konseling standar hanya 5 orang $(26,3 \%)$ dari 25 responden dengan nilai $\mathrm{p}=0,009$.

Berkaitan dengan adanya sebagian kelompok perlakuan yang pada akhirnya menggunakan vasektomi setelah diberikan konseling berdasarkan teori HBM diduga didukung oleh peningkatan pengetahuan, sikap, dukungan istri, panutan/ keteladanan dari motivator $\mathrm{KB}$ pria yang mungkin pengalaman yang diberikan lebih nyata, dan adanya upaya pemerintah Kota Banjar untuk meningkatkan angka cakupan vasektomi adalah dengan memberikan bantuan jaminan pelayanan keluarga berencana (jadup) yaitu: Biaya jaminan pelayanan keluarga berencana medis operasi pria (MOP) sebesar Rp. 250.000,-. Namun begitu, masih ada responden yang tidak menggunakan vasektomi meskipun telah diberikan konseling dan terjadi peningkatan pengetahuan, sikap, dukungan istri maupun panutan/keteladanan, ini terjadi karena ada beberapa hal diantaranya anggapan negatif/rumor negatif terkait vasektomi, trauma vasektomi yang lama, budaya, minimnya informasi mengenai vasektomi dan alasan agama. Bila dikaitkan dengan nilai suami istri dalam keluarga yang dianut oleh sebagian besar masyarakat, hal ini erat kaitanya dengan suami merupakan pengambil keputusan utama, tetapi vasektomi itu merupakan metode kontrasepsi jangka panjang yang kurang diminati para pria. Diharapkan dengan meningkatnya dukungan istri dan panutan/ keteladanan dari tokoh masyarakat akan mendorong suami untuk berpartisipasi dalam KB pria vasektomi. ${ }^{21,22,23}$

Hasil penelitian Basuki menunjukkan bahwa penggunaan komunikasi face to face efektif dalam penerimaan metode vasektomi. Dalam hal ini testimoni merupakan faktor penting dalam penciptaan opini dan perilaku calon peserta vasektomi. Komunikasi face to face merupakan strategi efektif untuk mengubah perilaku (menjadi peserta vasektomi). ${ }^{22}$

Pengetahuan yang meningkat akan meningkatkan perilaku ber-KB. Dari berbagai penelitian, perilaku yang didasari oleh pengetahuan akan lebih langgeng daripada perilaku yang tidak didasari oleh pengetahuan. Sebelum mengadopsi perilaku baru, terjadi proses yaitu kesadaran, ketertarikan, menimbang dan mencoba. Apabila adopsi perilaku didasari oleh pengetahuan dan sikap yang positif, maka perilaku tersebut akan bersikap langgeng. ${ }^{24}$

Konseling HBM dalam penelitian ini disampaikan agar dapat menggali/ mengeksplorasi masalah klien, sehingga klien dapat merubah persepsi dan menyadari masalah kebutuhannya sendiri dalam mengambil keputusan ber-KB yang sesuai dengan kondisi kesehatannya. Konseling HBM berisi tentang perceived susceptibility menyadari faktor risiko/kerentanan yang dialami oleh istri apabila istri tidak memungkinkan ikut ber-KB dikarenakan adanya faktor resiko yang akan mempengaruhi kesehatan istri peningkatanya sebesar $68 \%$, perceived severity menyadari keparahan apabila terjadi kegagalan ber-KB pada istri atau terjadi kehamilan yang dapat membahayakan keselamatan jiwa istrinya peningkatanya sebesar $76 \%$, perceived benefits menyadari manfaat vasektomi efektivitas tinggi $(99,85 \%)$ untuk mencegah kehamilan, aman, lebih ekonomis peningkatanya sebesar $80 \%$, perceived barriers menyadari hambatan dikarenakan dilakukan dengan tindakan medis/ pembedahan, maka masih memungkinkan terjadi komplikasi, seperti perdarahan, nyeri dan infeksi peningkatanya sebesar $68 \%$, cues to action isyarat untuk bertindak, keputusan calon akseptor harus memenuhi azaz sukarela peningkatanya sebesar 68\%, dan self eficacy, suami mau menjadi akseptor vasektomi karena suami mempunyai hak dan peluang yang sama dengan istri untuk menjadi akseptor KB vasektomi peningkatanya sebesar $56 \%$. Konseling ini merupakan proses kolaborasi antara konselor dan klien yang bertujuan untuk memberdayakan klien dalam menanggapi masalah yang dihadapi. Hal yang perlu diingatkan dalam proses konseling adalah kebebasan dan tanggung jawab yang dimiliki klien terhadap dirinya, serta mampu mengembangkan potensi dirinya berdasarkan kondisi dan masalah yang dihadapi, daftar kehendak atau pilihan keputusan yang dibuat dan konsekuensi dari tiap pilihan yang ditinjau dari sisi positif dan negatif.

Konseling HBM ini dapat memprediksi bahwa seseorang lebih termotivasi untuk mengambil tindakan kesehatan jika ancaman 
dirasakan oleh dirinya atau keluarganya dan apabila manfaat dengan melakukan tindakan tersebut diperkirakan lebih besar daripada hambatannya. HBM menggambarkan bahwa motivasi atau niat menentukkan perilaku kesehatan. Teori HBM ini bukanlah satusatunya teori perilaku yang menjadi dasar dalam perubahan perilaku klien dalam keikutsertaan $\mathrm{KB}$ pria vasektomi karena terdapat faktor lain yang berpengaruh dalam hal tersebut, ${ }^{13,16,17,19}$

\section{Keterbatasan Penelitian}

Penelitian ini Quasi eksperimen sangat mungkin terjadi bias karena subjek penelitiannya adalah manusia yang memiliki akal fikiran sehingga sadar bahwa mereka sedang diteliti. Penelitian ini hanya menggunakan kuesioner untuk mengukur variabel yang diteliti, sehingga peneliti tidak bisa menggali secara mendalam faktor lain yang mempengaruhi keikutsertaan pria PUS terhadap vasektomi. Tenggang waktu penelitian yang terbatas, suami yang baru pertama kali diberikan konseling tentang vasektomi, masih kuatnya dukungan istri di daerah penelitian, serta tidak adanya perlakuan pada istri dan keluarga responden, motivator vasektomi, kader maupun PLKB memungkinkan adanya pengaruh yang muncul dari pihak luar terhadap keputusan untuk menjadi akseptor vasektomi.

Dalam penelitian ini pengambilan sampel menggunakan stratified random sampling yang setiap desa nya memiliki jumlah sasaran vasektomi yang berbeda, namun setiap desa diambil 1 orang sasaran baik untuk kelompok perlakuan maupun kelompok kontrol, sehingga dalam penelitian ini tidak menggunakan prinsip bahwa semua sampel mempunyai hak yang sama untuk diteliti.

Sebanyak 4 orang bidan yang terlibat dalam memberikan konseling dan 4 orang pemotivator KB pria vasektomi yang memberikan testimoni, hal tersebut menyebabkan informasi yang didapat oleh responden kemungkinan berbeda-beda.

Adanya penambahan waktu penelitian menjadi 2 bulan 4 hari dikarenakan adanya responden yang merasa belum siap untuk menerima konseling vasektomi dan menunggu kesiapan klien dalam menerima konseling.
Sekalipun responden telah diberikan konseling berdasarkan teori HBM masih ada subjek penelitian yang pengetahuan dan sikapnya meningkat namun belum ikut serta menjadi akseptor vasektomi diduga karena dalam penelitian ini tidak semuanya melibatkan istri atau pasangan.

\section{Simpulan}

Konseling berdasarkan teori Health Belief Model tentang vasektomi lebih baik dibandingkan konseling standar dalam meningkatkan pengetahuan dan keikutsertaan vasektomi pria PUS. Saran Konseling berdasarkan teori Health Belief Model tentang vasektomi dapat digunakan dalam program penyuluhan pada masyarakat, dan dapat menjadi bahan masukan untuk pemegang kebijakan dalam merencanakan kebijakan yang berkaitan dengan strategi untuk meningkatkan promosi KB pria Vasektomi.

\section{Daftar Pustaka}

1. BKKBN, Panduan pelaksanaan KIP/Konseling kontrasepsi pria. Jakarta: BKKBN; 2008

2. BKKBN, Panduan pelayanan vasektomi tanpa pisau. Jakarta: BKKBN; 2008

3. Ekarini SMB. Analisis faktor-faktor yang berpengaruh terhadap partisipasi pria dalam keluarga berencana di kecamatan Selo Kabupaten Boyolali. Semarang: UNDIP; 2008

4. Tiya, Kadir, Dampak Intervensi Model Penurunan Unmeet Need KB dan Peningkatan KB Pria terhadap Pencapaian Sasaran Program DHS-I Pada Program KB di provinsi Sulawesi Tenggara. 2002.

5. Khotma FN, Palrto B, Julianti HP. Hubungan pengetahuan dan sikap istri dengan pemilihan kontrasepsi vasektomi pada pasangan usia subur. Semarang: UNDIP; 2011

6. Indrayani, Perbandingan Kualitas Hidup Antara Akseptor Vasektomi Dengan Pria Non Vasektomi Di Kecamatan Kiarapedes Kabupaten Purwakarta. Bandung: UNPAD; 2013

7. Budisantoso SI, Faktor-faktor yang berhubungan dengan Partisipasi Pria Dalam Keluarga Berencana di Kecamatan Jetis Kabupaten Bantul Tahun 2008. Semarang: UNDIP; 2008

8. Bunce A,Guest G, Searing H, Frajzyngier V, Riwa P, Kanama J,et al, Factors Affecting Vasectomy Acceptability in Tanzania, International Family planning perspective: 2007 ; 33(1):13-21

9. Adongo PB, Tapsoba P, Phillips JF, Tabong PT, Stone A, Kuffour E, et al, If you do vasectomy and come back here weak, I will divorce you: aqualitative study of community perceptions about vasectomy in Shouthern Ghana, Bomed Central; 2014; 1472-698X/14/16

10. Akindele RA, Adebimpe WO, Encouraging male involvement in sexual and reproductive health: 
family Planning service provider's perspectives, International Journal of reproduction Contraception, Obstetrics and Gynecology, ISSN 2320-1770; 2013; 2(2):119-23

11. Bayray A, Assessment of male involvement in family planning use among men in south eastern zone if Tigray, Ethiopia, Scholary Journal of Medicine, ISSN 2276-7134, Vol 2 (2); 2012

12. Simanulang, R., Pengaruh Faktor predisposisi, pemungkin dan penguat peserta kontrasepsi pria terhadap penggunaan vasektomi di Kecamatan Labuhan Deli Kabupaten Deli Serdang Medan. 2011.

13. Jadmiko AW, Sulastri. Pengaruh Pendidikan Kesehatan terhadap Perubahan Pengetahuan dan Sikap Suami Tentang Vasektomi di Desa Jeruk, Wilayah Kerja Puskesmas Miri, Kabupaten Sragen; 2006

14. Glanz, K., Rimer, B.K., Viswanath, K.. Health Behavior And Health Education (Theory, Research and Practice), 4th Edition. USA : Jossey Bass; 2008

15. Wahyuni NPDS, Suryani N, Murdani P, Hubungan Pengetahuan dan Sikap Akseptor KB Pria Tentang Vasektomi serta Dukungan Keluarga Dengan Partisipasi Pria Dalam Vasektomi (Di Kecamatan Tejakula Kabupaten Buleleng). Jurnal Magister Kedokteran Keluarga, UNS; 2013

16. Riauwi HM, Hasneli Y, Lestari W. Efektivitas Pendidikan Kesehatan Dengan Penerapan The Health Belief Model Terhadap Pengetahuan Keluarga Tentang Diare. Program Studi Ilmu Keperawatan Universitas Riau, 2014

17. Hall K.S, The Health Belief Model Can Guide Modern Contraceptive Behavior Research And Practice. J. Midwifery Women Health, Princeton University.2013
18. Bayat F,Shojaeezadeh D, Baikpour M, Heshmat R, Baikpour M, Hosseini M, The effects of education based on extended health belief model in type 2 diabetic patients: a randomized controlled trial. Journal of Diabetes \& Metabolic Disorders 2013

19. Simanjuntak RS. Tingkat adopsi inovasi KB pria di kalangan prajurit wilayah Medan tahun 2007. Medan: 2007

20. Widyastuti S, Pengaruh Konseling Apoteker Terhadap Pengetahuan, Persepsi, Kepatuhan dan Kadar Glukosa Darah Berdasarkan Health Belief Model Pada Pasien Diabetes Melitus Tipe 2 Di RSUD Lamaddukuuelleng Kabupaten Wajo Sulawesi Selatan. IKM, UNPAD, 2013

21. Mahamed F. Impact Of Familiy Planning Health Education On The Knowledge And Attitude Among Yasoujian Women. Global Journal Of Helath Science. 2012. Vol 4(2)

22. Rahmawaty. Evaluasi Program Keluarga Berencana Pria (Vasektomi) di Kecamatan Bukit Kecil Palembang Tahun 2011. Jurnal Ilmu Kesehatan Masyarakat, 3(03).pp.213-20. ISSN 2086-6380

23. Basuki, Panji DA, Strategi KIE Metode Vasektomi/ MOP Dalam Upaya Peningkatan Akseptor KB Pria Lestari di Kabupaten Badung Kota Surabaya. UPN "Veteran" Yogyakarta

24. Widowati N, Agus JP, Agus H, The Achievement of Male Family Planning Program: Vasectomy in Dlingo And Sewon Districts, Bantul Region, 2010

25. Sariyono, Noor S, Buchari MA, Hubungan Pengetahuan Sikap Pria Tentang Keluarga Berencana Dengan Partisipasi Pria Dalam Pemakaian Metode Kontrasepsi Keluarga Berencana Di Kabupaten Barito Kuala. Jurnal Ilmu Kesehatan. 2007;3(1) 